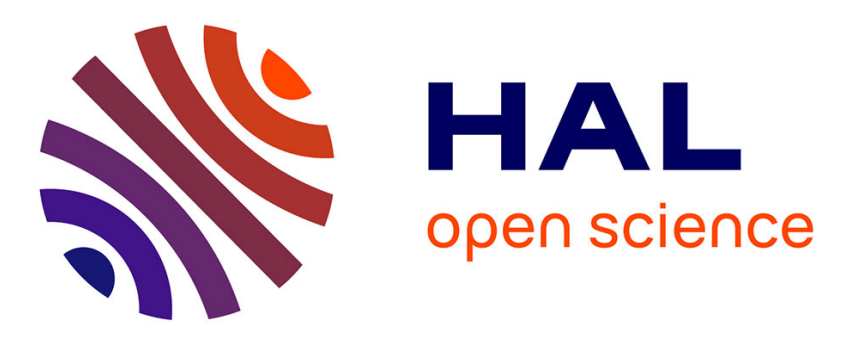

\title{
Orcc's Compa-Backend demonstration
}

Yaset Oliva, Emmanuel Casseau, Kevin Martin, Pierre Bomel, Jean-Philippe

Diguet, Hervé Yviquel, Mickael Raulet, Erwan Raffin, Laurent Morin

\section{To cite this version:}

Yaset Oliva, Emmanuel Casseau, Kevin Martin, Pierre Bomel, Jean-Philippe Diguet, et al.. Orcc's Compa-Backend demonstration. Conference on Design and Architectures for Signal and Image Processing, Demo Night, Oct 2014, Madrid, Spain. 2014. hal-01059858

\section{HAL Id: hal-01059858 \\ https://inria.hal.science/hal-01059858}

Submitted on 23 Oct 2014

HAL is a multi-disciplinary open access archive for the deposit and dissemination of scientific research documents, whether they are published or not. The documents may come from teaching and research institutions in France or abroad, or from public or private research centers.
L'archive ouverte pluridisciplinaire HAL, est destinée au dépôt et à la diffusion de documents scientifiques de niveau recherche, publiés ou non, émanant des établissements d'enseignement et de recherche français ou étrangers, des laboratoires publics ou privés. 


\section{Orcc's Compa-Backend demonstration}

Yaset Oliva, Emmanuel Casseau, Kevin Martin, Pierre Bomel, Jean-Philippe Diguet, Hervé Yviquel, Mickaël Raulet, Erwan Raffin, Laurent Morin.

\section{Abstract}

This work presents the implementation of an MPEG-4 part 2 video decoder, from its high-level description to the system implementation, using the Orcc's Compa-Backend. The high-level description consists of a data flow model (a network of actors) and the functional description in language CAL for each actor.

The target HW architecture is a shared-memory multiprocessor embedded system.

\section{Introduction}

More complex communication and video standards and more powerful and heterogeneous multi-core hardware architectures, make the design of modern electronic systems an arduous process. New tools such as the Open RVC-CAL Compiler (ORCC) emerge to help overcome the challenges of the new designs.

Our goal in this work is to validate a new extension to the Orcc framework for multiprocessors embedded systems.

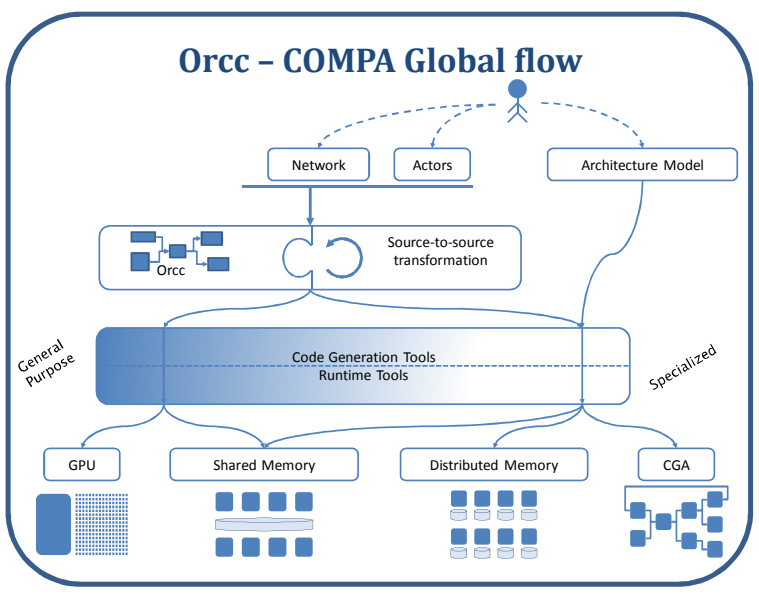

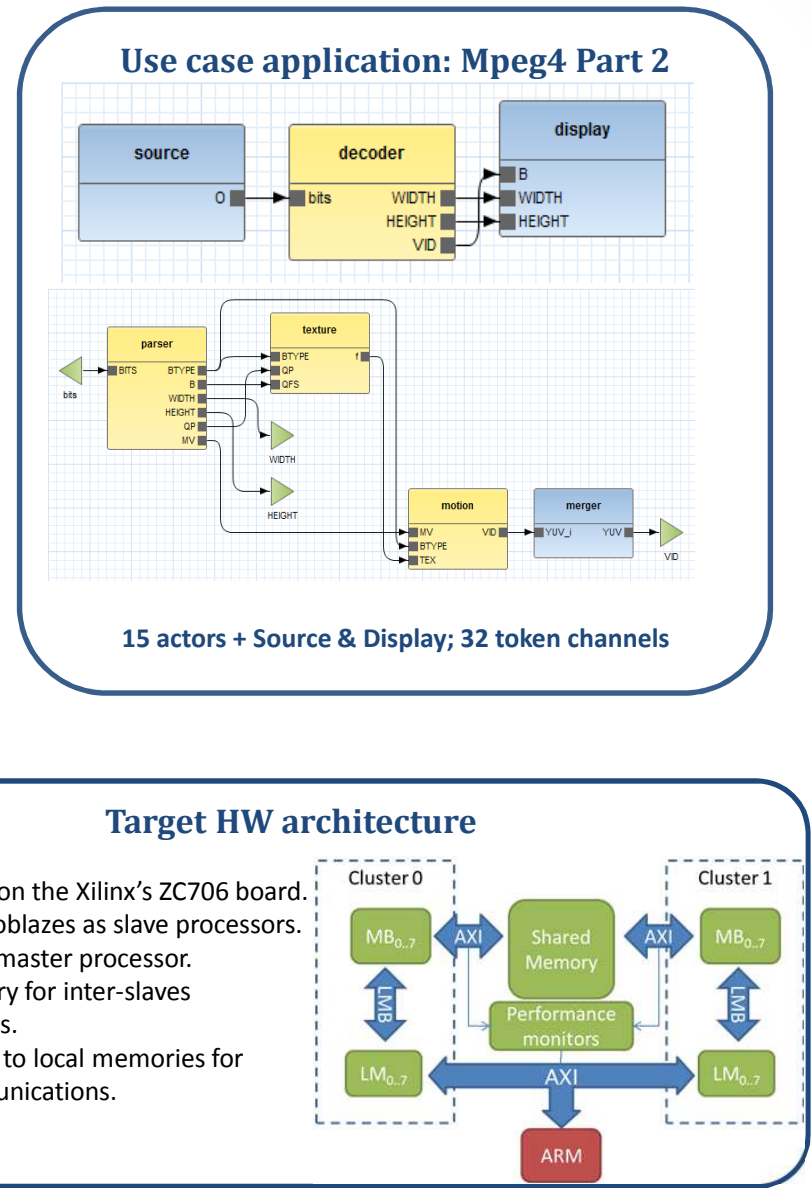

- Implemented on the Xilinx's ZC706 board.

- Up to 16 Microblazes as slave processors.

- 1 ARM as the master processor.

Shared memory for inter-slaves data exchanges.

- Master access to local memories for control communications. nutnut metrics
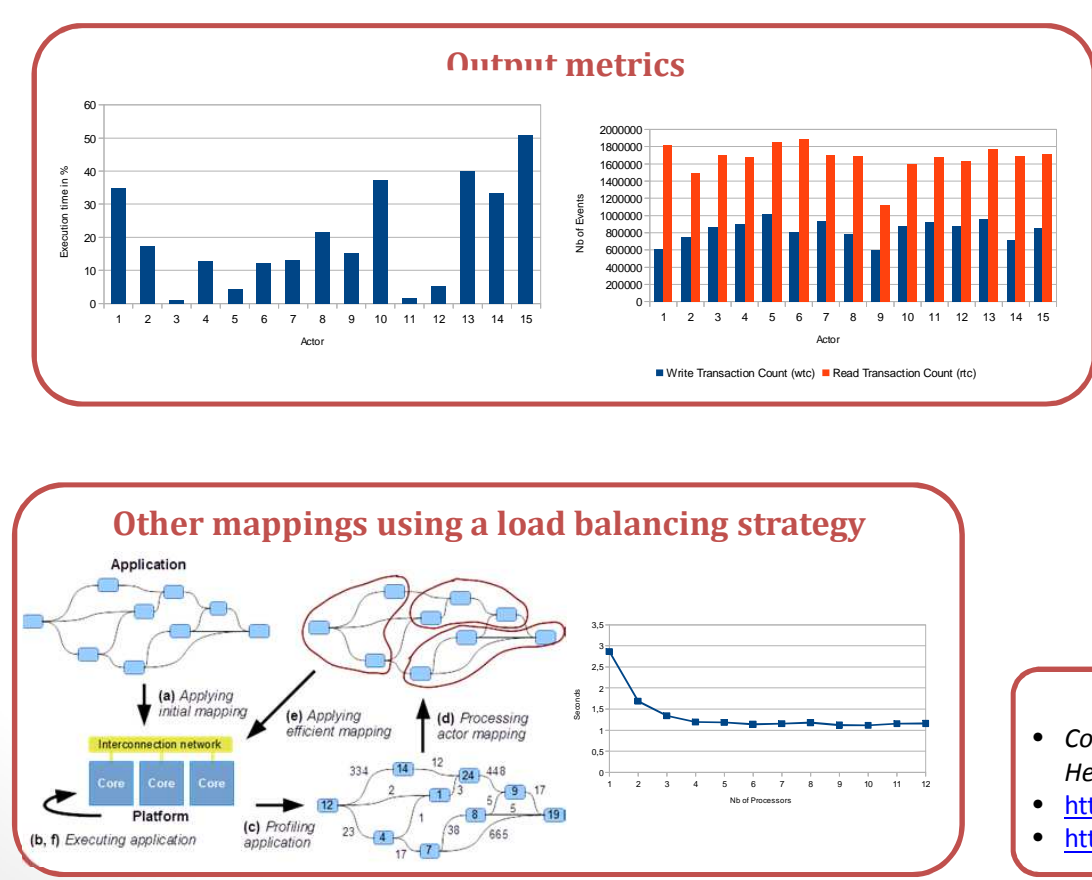

- Communication-model based Embedded Mapping of Dataflow Actors on Heterogeneous MPSoC. DASIP-14 Session \#6 (next Friday)

- http://www.compa-project.org/

- http://orcc.sourceforge.net/ 